\title{
Pela Dignidade e Segurança da Patria
}

"Dulce et decorum est pro patria mori" Hor.

Joâo Arruda

\section{ORIGEM DESTE ARTIGO}

Ao tempo em que foi torpedeado pelos alemães o Paraná (1917), apresentei à congregação da Faculdade de Direito de São Paulo uma indicação, mostrando a necessidade de armar-se nossa pátria para manter intacta sua honra, e para defender-se contra qualquer agressão estrangeira. Queria eu patentear que a corporação científica à qual fôra confiada a educação dos moços a quem seriam entregues os destinos do Brasil não era alheia à dôr que pungia o coração de todo filho deste abençoado torrão.

As primeiras palavras de minha indicação mostram o espírito que a ditou. Ei-las. "Entendo que se torna necessário aproveitar este momento de justa indignação contra os atos praticados pela Alemanha para tratar de organizar a nossa fôrça, tornando nossa pátria capaz de resistir a qualquer violência do estrangeiro. É, porém, minha opinião que os povos fortes, geralmente denominados potências, nada ficam a dever à Alemanha quando em face dos fracos, e que consequentemente cumpre nos precatemos contra qualquer abuso que tentem contra o Brasil"

Como houvesse, na indicação, diversas narrativas de atos de violências infligidas aos povos fracos pelos fortes, en- 
tendi que era imprudente publicar-se meu trabalho naquele momento de agitação universal, quando a guerra se achava em seu auge. Requeri, pois, que se enviasse a minha proposta ao Ministério da Guerra, e que fosse ela mantida secreta, como autorizam as nossas leis.

Julgo oportuno reproduzir algumas considerações então formuladas no intento de manter alerta nossos patrícios, embora felizmente seja verdade que os nossos govêrnos não se teem descuidado do serviço militar, quer antes, quer depois de 1930. A necessidade da existência do exército nacional, ou formado pelos que não são profissionais na arte bélica, compreendendo todos os cidadãos, é hoje uma idéia vencedora, e aceita por nós e por outros povos. Se todos os homens quisessem manter-se numa paz constante, se todos se mostrassem convencidos da verdade do anguelismo, segundo o qual são aparentes, e não reais os proveitos da guerra, mesmo para o vencedor, o desarmamento sería a única política a ser adotada por todos os homens cultos. Mas não: ha sempre um inimigo pronto para atirar-se contra os povos menos acautelados, e particularmente contra os mais ricos, em cujo número se acha a nossa pátria. Sem alusão aos atuais povos cultos, devo mencionar uma lenda dos selvagens sulamericanos que é contada por Southey. E' a dos Mbayas. Diz assim o escritor, segundo a tradução de Oliveira e Castro. “A tradição dos guaycurús a respeito de sua própria origem é ter Deus no princípio creado todas as outras nações, tão numerosas como hoje são, repartindo entre elas a terra. Mais tarde creou dois Mbayas, varão e mulher, mandando-lhes dizer pelo caracará (falco brasiliensis) que sentia não restar mais parte alguma do mundo para lhes dar, pelo que só creára dois, mas que vagassem pelo patrimônio dos outros, fazendo-lhes eterna guerra, matando os adultos varões e aumentando seu próprio número adotando as mulheres e as crianças. Nunca, diz Azara, foi preceito divino mais lealmente cumprido" 


\section{O PERIGO}

Em todos os tempos, houve, sempre, em alguns povos, a tendência para se expandirem com prejuizo dos vizinhos, e, mais tarde, dos ocupantes de terras afastadas, remotas. Tomou esta inclinação modernamente o nome de imperialismo, mas é a tendência tão antiga quanto o genero humano, e explica o espírito guerreiro dos impérios da Assíria, Babilônia e da Pérsia.

Em certas épocas, acentua-se este movimento que se transformou, ao tempo da invasão dos bárbaros, em um cataclismo para o mundo civilizado. Alexandre Magno, que só pela revolta de seus soldados, cançados de lutar, foi detido na sua marcha para o Oriente, em busca da fndia; Annibal, transpondo os Alpes e pondo em perigo Roma; Cesar conquistando as Gállias e voltando-se para o Oriente; Carlos Magno na sua mania de alargar os limites do seu império; Napoleño I, incomodando o mundo inteiro, até ser vencido pela coligação dos povos que desejavam trabalhar, todos são indivíduos que indubitavelmente mais acirraram a barbárie do genero humano, sedentos de sangue e das riquezas dos povos irmãos.

Ninguem acredita em guerra, diz o conhecido mestre IHERING, em sua "Luta pelo Direito", senão quando ouve o primeiro tiro" Ela está contudo sempre iminente, e ái do povo que dorme tranquilamente, confiado na bôa vizinhança.

Ensinar aos nossos compatriotas quanto é danosa a guerra (sem lhes narrar os horrores dela, como abaixo direi), mostrando-lhes quão exata é a doutrina do anguelismo, segundo a qual todos perdem na luta, mesmo os vencedores, mas prepará-los para o combate quando ultrajada a pátria ou ameaçada em sua existência, eis a diretriz que deverá ser seguida. 


\section{O SACRIFfCIO}

Diz Spencer em sua obra "Justiça" que nenhuma sociedade pode manter-se sem o sacrifício de alguns de seus membros. Isto, que se dá mesmo nos animais inferiores, é o que justifica o serviço militar obrigatório nas sociedades humanas. Mas não basta obrigar o recruta a marchar para o campo cruento: é indispensavel ter ele a instrução militar que ha de ser dada em tempo mais ou menos longo. Conta-se que, nos últimos tempos das guerras de Napoleño I, esgotadas todas as suas reservas, recorreu ele aos rapazes que nunca haviam manejado uma espingarda. Em pleno combate, notou que um batalhão desses moços não respondia ao fogo feito contra ele. Ordenou que os rapazes atirassem, e eles, não obedeceram. Tomou de uma espingarda, e ele próprio fez fogo. Os soldados observaram como operava o imperador com a arma, e abriram fogo imediatamente: tinham aprendido como se usa de uma espingarda. Se non é vero. Conheço porém fato cuja veracidade posso assegurar. Durante a luta de 1932, um oficial improvisado, paisano que nunca víra uma metralhadora, não sabia, quando os soldados iniciaram o combate, como manejar o instrumento de guerra!!!. Bravura por si só não basta: é necessária alguma instrução militar.

Com todas as restrições impostas à Alemanha pelos aliados, soube ela perseverantemente educar para a guerra seus filhos: planadores, desportos atléticos, exercícios aquáticos em barcos que nenhuma aparência tinham de naves de guerra, corporações de tiro ao alvo, estudos de natureza propedêutica para a instrução militar, para conhecimento da arte bélica, eis o que foi sua idéia fixa, e que a levou ao poderio de hoje. Não é só: enquanto, nos outros povos, inspirava-se o pavor pela guerra com as obras de Remarque, estas eram proibidas na pátria de Bismark e Moltke.

Quando se procedia á conscrição em França, houve alguns pacifistas que pediram a ZoLA licença para dar uma edição barata da "Débâcle", afim de inspirarem, com o 
romance do grande literato, aversão às lutas nos sangrentos campos de batalha. Respondeu-lhes o romancista que, se era uma necessidade fossem os moços para as fileiras do exército, êrro grave sería abrir-lhes os olhos para o que é essa fatalidade que se chama guerra, sendo-lhes impossivel evitar que os fatos arrastassem a França a uma luta sanguinosa e horrivel. O romance era muito bom para ser lido por alguns dos dirigentes dos destinos da pátria que tivessem coração humano: para os obscuros soldados, não.

A par da instrução que deve ter o cidadão destinado ao exército, e que continúa entretanto paisano, cumpre não esquecer a disciplina que deve reinar no serviço militar, de fórma que a mobilização se faça, tanto quanto possivel, como foi efetuada por Moltke, segundo é de tradição: continuou a sossegadamente jantar, dizem uns, continuou tranquilamente a dormir, dizem outros, depois que indicou como estava organizada toda a mobilização numa das gavetas de sua secretaria. Não havia soldado que não soubesse o corpo a que pertencia, não havia batalhão que não estivesse informado do logar onde deveria apresentar-se. Geralmente diz-se, com certa razão, que o exército alemão, com os soldados profissionais e os recrutas, era um verdadeiro relógio, funcionando admiravelmente.

A bravura de ScIPiño, o Africano, diz Machiavel, comunicada a seus soldados, era insuficiente para a continuação de seus triunfos por causa de seu desleixo na disciplina, e, por isto, o senado romano se viu, não raro, obrigado a substituí-lo, não obstante ser ele estrênuo defensor da pátria.

\section{O CHEFE}

Em toda a organização militar, do mesmo modo que em tudo em nossa vida, ha sempre um fato aleatório, e vem a ser, nas lutas sanguinosas, a capacidade ou incapacidade do chefe.

Ouvi de muitos veteranos do Paraguai que o $5 .^{\circ}$ batalhão foi apelidado Quinto Curto, porque seu comandante, 
homem cobarde, sempre tinha por voz de comando "Quinto, curto", isto é, passo curto, para chegar depois de findo o perigo. Ia ser dissolvido por cobarde o batalhão, que era sempre o primeiro a fugir em debandada vergonhosa. Certo brioso oficial fez sentir ao general que sería para o Brasil e para os soldados que compunham o corpo, uma nódoa indelevel a dissolução. Pediu lhe fosse dado comandar o $5 .^{\circ}$. Concedida a licença pedida, os soldados do 5. foram transformados, como por milagre, em leões ou tigres. Nunca se viu bravura igual. Sucedeu que, ao ser tomado um reduto, morreu o novo capitão, ficando o cadáver na parte das forças paraguaias. Pois bem. Os heróicos soldados do $5 .^{\circ}$ atiraram-se, como si fossem verdadeiras feras, sobre os inimigos afim de conquistarem o corpo de seu capitão morto, e dar-lhe as honras fúnebres a que têm direito os que vão dormir o sono dos bravos.

Para ser feita uma idéia do que é um chefe, basta lembrar os fatos históricos ocorridos ultimamente na Abissínia. Qual a diferença entre a Abissínia de 1896 e a atual, entre a Itália de Ádua e a vitoriosa ultimamente? A resposta parece facil: bom chefe abissínio o negus Menelioue II em 1896. e máos chefes italianos: hoje, máo chefe abissínio e bom chefe italiano. Os povos eram os mesmos.

E' ainda eloquente a resistência de Nicarágua, o país de 500 mil habitantes, sob o comando de Sundino contra todas as forças da América do Norte!

\section{CULTO DOS HEROIS}

Si é certo que o chefe é de influência decisiva na guerra, do mesmo modo que em outros casos, não é menos verdade que o respeito áqueles que pela pátria morreram estimula o patriotismo, e torna mais forte um país que tenha de envolver-se em luta de qualquer gênero. Infelizmente só agora começou no Brasil a ação louvabilíssima governamental em prol do respeito pelos que se sacrificaram pela sociedade. Concorreu muito para o desrespeito dos nossos 
herois a opinião, tão ridicularizada por Washington Invnng, de que na América tudo degenera, tudo é inferior ao que ha na velha Europa. Sem verem as metrópoles o que foi a luta pela independência das colônias americanas, continuaram na crença de que a América é uma terra de fracos, e onde será impossivel aparecer um heroi da estatura dos que abundam no Velho Continente desde os tempos mais remotos.

Deixar em esquecimento um bravo é diminuir-lhe em muito o pagamento da dívida que a nação tem para com ele. Os historiadores e poetas muito contribuiram para eternizar a gloria dos que se sacrificaram para terem um nome imorredouro. Foi pois com toda a razão que Cícero, na sua oração pelo Archia, deixou, referindo-se a AlexanDRE MAgno, as seguintes palavras: "Cum in Sigeo ad Achillis tumulum astitisset. $O$ fortunate, inquit, adolescens, qui tuae virtutis Homerum praeconem inveneris. Et vere. Nam nisi Ilias illa extitisset, idem tumulus, qui corpus ejus contexerat, nomen etiam obruisset"

Por outro aspecto tomado o assunto, nada mais danoso que semear o descrédito em prejuizo de nossos bravos. Apresentarei um exemplo.

Relatando oficialmente o marechal Floriano Peixoto haver sufocado a revolta da armada, afirmou, obnubilado pela cólera, terem dado nossos marinheiros prova de cobardia. Quais as consequências? Pouco depois, no congresso legislativo, havia o incidente em que representaram os deputados paulistas, particularmente o padre Valois e o coronel Fernando Prestes, papeis de destaque. Nos Estados Unidos o almirante Benheim afirmava, em resposta a um discurso de Mac MaHon (inimigo conhecido do Brasil), que todos os brasileiros tinham medo dos norteamericanos (Eduardo Prado, "Ilusão Americana", pag. 134). Sabemos todos ter BENHEIM sido um almirante que, durante a revolta de 1893 , se mantinha com seus navios no meio da baía Guanabara, de medo de febre amarela ("Notas de um Revoltoso", pag. 181). Não parou aí o efeito da oração de Floriano. Em 
São Paulo, na capital, certo medico português, em uma conferência, diante de seleto auditório, fez variações sobre o tema dado pelo marechal, e pretendeu divertir os ouvintes com chufas picantes, e até obcenas, sobre a cobardia de Custodio de Melo. E. triste é dizê-lo, não houve nem um só protesto, quer do auditório, quer da imprensa desta culta capital. Refiro sine ira et studio estes fatos, conquanto tenha o coração de patriota despedaçado pela dôr causada pela injúria sangrenta atirada ás faces do Brasil.

Embora tenham sido tomadas pelos nossos governantes medidas dignas de aplauso para manter intacta a dignidade da pátria, o fato é que, particularmente pelos trabalhos das estações de rádio, ela sofre, não raro, atentados. TiradenTES, o bravo e intemerato protomartir, foi objeto de ridículo em uma irradiação. Nas praças públicas mesmo, secundando a difamação radiofônica, viram os habitantes desta cidade a estátua do patriarca da Independência profanada pormãos de indivíduos de sentimentos vis.

\section{OPERARIOS E SERVIÇO MILITAR}

Por má compreensão da necessidade social de defesa, teem sido os operários, em elevado número, inimigos das forças armadas. Iludidos por uma fraternidade que não existe, julgam que os operários de outros paises, sendo seus irmãos, lhes querem. tanto quanto seus patrícios. Chegam a negar a idéia de pátria. E' a seita internacionalista a que mais ódio vota á guerra e ao exército. Terão razão, em futuro muito remoto, e que não chegará quiçá antes do juizo final, quando houver a paz perpétua, e se realizar o sonho que teve Anatole France "sur la pierre blanche"

Como, porém, teem procedido os govêrnos para que vençam ésta resistência, e submetam o operário á conscrição?

Ao ser iniciada a grande guerra, vieram os operários de uma fábrica alemã dizer ao oficial militar que não se submeteriam á mobilização por considerarem os francesas seus. 
irmãos, e não seus inimigos. $\mathrm{O}$ oficial respondeu-lhes que Ihes ia tirar o escrúpulo, e mandou fossem passados pelas armas. Conta-se que, recusando-se ultimamente os trabaIhadores de certa fábrica da Alemanha ao aumento de horas de trabalho para preparo das munições de guerra, mandou Hitler que fossem metralhados. Si tais fatos não são verdadeiros, são verosimeis.

Em França, houve, faz pouco, uma manifestação operária em favor da paz, e, desfilando os manifestantes diante do túmulo do soldado desconhecido, escarravam-lhe em cima!. $O$ ato, além de cruel, era estúpido: que culpa tivera o soldado desconhecido na grande guerra? Que responsabilidade lhe cabia pela conflagração, pelo cataclismo que abalou o mundo inteiro?

Neste momento, ocupam-se os jornais com a dificuldade, que ha em estabelecer-se a conscrição em Inglaterra.

Que medidas adotar? As drásticas alemãs só devem ser postas por obra em último caso, como sendo uma ultima ratio: uma pena só é empregada quando não ha outros remédios.

Parece-me que deveriam os govêrnos fazer sentir aos operários que eles se enganam julgando que o patrão estrangeiro os tratará com a mesma brandura que o patrício. A verdade, porém, é que será o patrão alemão mais duro para com os operários franceses do que para com os seus patrícios, sucedendo o mesmo com os operários franceses que servirem ao chefe alemão. A prova ha aqui neste país, que é o mais hospitaleiro do mundo, onde o nosso govêrno tem sido forçado a proteger o braço nacional, da mesma fórma por que protege o brasileiro trabalhador nervoso ou inteletual.

Bom é que todos se convençam de que os solidaristas não deixam de ter razão quando afirmam que parte da rudez dos operários é devida á falta de educação, falta de que são culpados aqueles a quem se confiam os destinos da nação Esclarecer o operário, eis, creio, a obrigação dos dirigentes. 
Se a paz corre, a todo momento, perigo, porque povos amigos da guerra ameaçam aos que querem trabalhar, é certo que tambem dever é dos que dirigem os homens mostrar-lhes que razão teve Norman ANGEL, quando afirmou ser a guerra sempre um máo negócio: consequentemente devemos evitá-la, não lhe dar ocasião, embora prontos para suportar-lhe os horrores. Queremos a paz, mas sem sacrifício nem da existência da nação, nem de sua dignidade.

\section{UM CAPfTULO A NÃO SER PUBLICADO}

Já disse eu acima que IHERING assevera ninguem acreditar em guerra antes de ouvir o primeiro tiro. Era ocasião para mostrar eu quais os mais provaveis fatores de luta para o Brasil, mas os calarei por prudência e discrição. Aqui o povo não crê seja possivel acidente belicoso, conquanto tenha visto, ha bem pouco, as guerras do Chile contra a Bolívia e o Perú e a do Chaco.

Falarei em geral.

A História nos mostra, aparecendo um Alexandre Magno, um Anibal, um Carlos Magno, um Napoleão, inquietando estes conquistadores o mundo inteiro. Jsto no espaço de muitos séculos. Outras vezes o fenômeno se repete de modo assustador. Em meus dias, já vi por três vezes a Alemanha contra o mundo culto: a primeira vez com Bismarck, a segunda com Guilherme II, e a terceira agora com Hitler. Impossivel, pois, fazer a respeito das ameaças de guerra cálculo de probabilidades. Indispensavel é que estejamos preparados para qualquer surpresa, lembrados de que é verdade importantíssima a proclamada por IHERING, já tantas vezes por mim citada neste artigo.

Concluindo, pois, direi que merece todo o meu apôio quanto fizer o govêrno para defesa da pátria, que só os imprevidentes julgam a salvo de qualquer agressão. 